\title{
Molecular Dynamics Study on the Effects of Charged Amino Acid Distribution Under \\ low pH Condition to the Unfolding of Hen Egg White Lysozyme and Formation of Beta
}

\section{Strands.}

Husnul Fuad Zein ${ }^{1,2}$, Ibra Alam ${ }^{1}$, Piyapong Asanithi ${ }^{1}$, and Thana Sutthibutpong ${ }^{1,2,3 *}$

${ }^{1}$ Nanoscience and Nanotechnology Program, Faculty of Science, King Mongkut's University of Technology Thonburi.

${ }^{2}$ Theoretical and Computational Physics Group, Department of Physics, KMUTT, Thailand. Faculty of Science, King Mongkut's University of Technology Thonburi.

${ }^{3}$ Center of Excellence in Theoretical and Computational Science (TaCS-CoE), Faculty of Science, King Mongkut's University of Technology Thonburi (KMUTT), 126 Pracha Uthit Rd., Bang Mod, Thung Khru, Bangkok 10140, Thailand.

*Corresponding Author: Thana Sutthibutpong, Ph.D.

Theoretical and Computational Physics Group, Department of Physics.

Theoretical and Computational Science Center (TaCS), Science Laboratory Building, Faculty of Science, King Mongkut's University of Technology Thonburi (KMUTT), 126 PrachaUthit Road, Bang Mod, Thrung Khru, Bangkok 10140, Thailand.

e-mail: thana.sut@mail.kmutt.ac.th 


\begin{abstract}
Aggregation of unfolded or misfolded proteins into amyloid fibrils can cause various diseases in humans. However, the fibrils synthesized in vitro can be developed toward useful biomaterials under some physicochemical conditions. In this study, atomistic molecular dynamics simulations were performed to address the mechanism of beta-sheet formation of the unfolded hen egg white lysozyme (HEWL) under a high temperature and low $\mathrm{pH}$. Simulations of the protonated HEWL at $\mathrm{pH} 2$ and the non-protonated HEWL at $\mathrm{pH} 7$ were performed at the highly elevated temperature of $450 \mathrm{~K}$ to accelerate the unfolding, followed by the $333 \mathrm{~K}$ temperature in some previous in vitro studies. The simulations showed that HEWL unfolded faster and refolded into structures with higher beta-strand contents at $\mathrm{pH} 2$. The mechanism of beta-strand formation at the earlier stage of amyloidosis was addressed in terms of the radial distribution of amino acids, affected by the high protonation level at a low $\mathrm{pH}$.
\end{abstract}




\section{Introduction}

Lysozymes are a family of globular enzymes in the immune systems of animals. A lysozyme molecule is a single polypeptide of around 130 residues that can partially hydrolyze the peptidoglycans of gram-positive bacterial cell walls [1,2]. Lysozyme is one of the protein types that are associated with the formation of amyloid fibrils under some specific conditions. The failure of specific peptides or proteins to fold or to remain correctly folded triggered nonfunctional protein aggregation and amyloidosis [3]. Amyloid aggregation is a hallmark of several degenerative diseases, such as Alzheimer's disease, Parkinson's disease, type II diabetes, Creutzfeldt Jakob, Huntington's, amyotrophic lateral sclerosis (ALS) [4,5]. However, it was suggested that nontoxic forms of amyloid fibrils could be utilized in some applications, such as bioengineering, biosensor, drug delivery, regenerative medicine, cell-encapsulating materials, tissue engineering, molecular and electronic devices, etc. [6-17].

Amyloid fibril formation in vitro can be controlled under some suitable environments by several factors that either stimulate or inhibit aggregation [18]. Hen egg-white lysozyme (HEWL) is one the most commonly used proteins in protein aggregation research due to its well-characterized structure and low cost. Unfolding and refolding of HEWL during amyloidosis could be accelerated under a high temperature and acidic condition. A previous study showed that amyloid fibrils were formed when incubating HEWL under the temperature of $65^{\circ} \mathrm{C}$ and $\mathrm{pH} 2$ for 196 hours [1].

Conformational changes of the unfolded, refolded, and aggregated proteins can be monitored by using several methods, such as atomic force microscopy (AFM), Raman spectroscopy, and electrochemical impedance spectroscopy (EIS) [19-21]. Under an elevated temperature and acidic condition, AFM could provide images of lysozyme aggregation at 
various incubation times by depicting the time-dependent sizes of self-assembled spheroidal oligomers. The changing of both the secondary and tertiary structures of the aqueous lysozyme could also be observed by the shifting of Raman spectra in the range of $650-1875 \mathrm{~cm}^{-1}$ from its native state [1]. Signals from EIS spectroscopy are highly sensitive to the changing of both secondary and tertiary structures of the protein due to their unique charge transfer resistances (Rct) [21]. These methods, along with dynamic light scattering, size exclusion chromatography, transmission electron microscopy (TEM), Fourier transform-infrared (FT-IR) spectroscopy, the surface plasmon resonance (SPR) [1,22,23], have their own advantages but still lack understanding in the molecular details of protein structural changes.

Computer simulations have become an alternative tool to provide more insight into the structures and dynamics of proteins at different states under different conditions in atomistic details. The accuracy of atomistic molecular dynamics (MD) simulations to predict the molecular behavior of proteins under extreme conditions [24,25] has been improved with the continuing development of molecular mechanics forcefield parameters [26,27]. Therefore, a number of computational studies were carried out to observe the effects of temperature, solvents, and external perturbation on the unfolding and aggregation of both human lysozymes and HEWL [25,28-34]. From MD simulations performed by Moraitakis et al., replacing an aspartic acid residue with a histidine caused human lysozyme to unfold significantly faster under high temperature and could reproduce an experimental result. The mutation was proposed as a possible seed for amyloidosis [25]. Jafari et al. demonstrated in molecular detail that the lysozyme unfolds better in high concentrations of the sodium dodecyl sulfate (SDS) surfactant at $370 \mathrm{~K}$, higher than the thermal denaturation midpoint temperature (Tm) [28]. Jiang et al. reported that high electric fields could enhance the possibility of protein unfolding due to the heterogeneous nature of charge distribution within proteins [29]. 
In our study, the effects of $\mathrm{pH}$ on the propensity of refolding and formation of beta-sheets that might lead to amyloidosis were addressed in atomistic details as the low $\mathrm{pH}$ condition was previously reported to facilitate amyloidosis. Additionally, the altered electrostatic properties due to the addition of positive charges during the protonation of some amino acids should affect denaturation and beta-strand formation. A series of MD simulations were performed under high temperature to accelerated unfolding processes, followed by simulations under an optimum temperature for amyloidosis reported in previous studies. Then, the conformational analysis was performed to characterize the simulated protein structures and provide the detailed mechanisms of beta-sheet formation under low $\mathrm{pH}$ and molecular insight of accelerating amyloidosis in vitro for further applications.

\section{Methodology}

GROMACS 2019.6 simulation package was used to carry out the Molecular Dynamics simulation. The initial atomistic structure of hen-egg white lysozyme was obtained from Protein Data Bank (PDB ID: 1AKI). In order to emulate $\mathrm{pH}$ conditions, protein coordinates were input to the PropKa software $[35,36]$ to estimate $\mathrm{pKa}$ values for aspartic acid, glutamic acid, and histidine residues. If the specified $\mathrm{pH}$ was lower than the $\mathrm{pKa}$ of a residue, the protonation state was assigned to that residue. At the $\mathrm{pH} 2$ condition, all histidines, glutamic acids, and aspartic acids were fully protonated. Meanwhile, at $\mathrm{pH} \mathrm{7,} \mathrm{all} \mathrm{the} \mathrm{aforementioned}$ amino acids were deprotonated. The lysozyme structures at both $\mathrm{pH}$ conditions were solvated by using the SPC216 water model within simulation boxes of size $6.9 \times 6.9 \times 6.9 \mathrm{~nm}^{3}$, which was large enough to cover a whole protein molecule with $1 \mathrm{~nm}$ buffer distance. As HEWL in both protonated and deprotonated forms were positively charged, all systems were neutralized by adding $\mathrm{Cl}$ - counter-ions. For each simulation, the energy minimization was performed with 
the steepest descent algorithm for the maximum number of steps of 50000. The short-range electrostatic cutoff distance and the short-range Van der Waals cutoff distance were $1.0 \mathrm{~nm}$. PME treatment was used to calculate long-range electrostatic interactions. Then, an NPT equilibration stage was performed at $\mathrm{T}=300 \mathrm{~K}$ and $\mathrm{P}=1$ bar for $200 \mathrm{~ns}$, which was long enough to accommodate the conformation changes from protonation states introduced at $\mathrm{pH} 2$. After that, three replicas of MD simulations at $450 \mathrm{~K}$ were performed for $100 \mathrm{~ns}$ to accelerate unfolding processes of both protonated $(\mathrm{pH} 2)$ and deprotonated $(\mathrm{pH} 7)$ structures. Then, all six simulations were continued at $333 \mathrm{~K}$ for $200 \mathrm{~ns}$ to emulate the in vitro condition that betastrand formation was observed. The summary of all MD simulations in this study is shown in Table 1.

All MD trajectory replicas at both $\mathrm{pH}$ conditions were then analyzed by the root mean square deviation (RMSD) calculations to quantify the level of protein unfolding and refolding from the global conformational changes compared with the reference PDB structure. The timedependent information of the secondary structure content of lysozymes at both $\mathrm{pH} 2$ and $\mathrm{pH} 7$ were analyzedanalyzed by the DSSP algorithm [37], which identified the type of secondary structure for all regions within the protein. During the unfolding process at $450 \mathrm{~K}$ and the refolding processes at $333 \mathrm{~K}$, the states of backbone torsions and alpha-beta transitions were monitored by Ramachandran plots for all simulation replicas at both $\mathrm{pH}$ conditions. The radius of gyration $(\mathrm{Rg})$ was calculated as functions of time for different amino acid groups of the HEWL to monitor the distribution of charged amino acids and hydrophobic amino acids during the protein unfolding and refolding processes. 
Table 1: All simulations in this study.

\begin{tabular}{|c|c|c|c|c|c|}
\hline pH & protein & replica & $\begin{array}{c}\text { Temperature } \\
\text { (K) }\end{array}$ & $\begin{array}{l}\text { Duration } \\
\text { (ns) }\end{array}$ & Dimension $\left(\mathrm{nm}^{3}\right)$ \\
\hline \multirow[t]{6}{*}{2} & \multirow{2}{*}{$\begin{array}{l}\text { Protonated- } \\
\text { HEWL }\end{array}$} & \multirow[t]{2}{*}{ R1 } & $450 \mathrm{~K}$ & $100 \mathrm{~ns}$ & \multirow[t]{2}{*}{$6.9 \times 6.9 \times 6.9 \mathrm{~nm}^{3}$} \\
\hline & & & $333 \mathrm{~K}$ & $200 \mathrm{~ns}$ & \\
\hline & \multirow{2}{*}{$\begin{array}{c}\text { Protonated- } \\
\text { HEWL }\end{array}$} & \multirow[t]{2}{*}{$\mathrm{R} 2$} & $450 \mathrm{~K}$ & $100 \mathrm{~ns}$ & \multirow[t]{2}{*}{$6.9 \times 6.9 \times 6.9 \mathrm{~nm}^{3}$} \\
\hline & & & $333 \mathrm{~K}$ & $200 \mathrm{~ns}$ & \\
\hline & \multirow{2}{*}{$\begin{array}{l}\text { Protonated- } \\
\text { HEWL }\end{array}$} & \multirow[t]{2}{*}{ R3 } & $450 \mathrm{~K}$ & $100 \mathrm{~ns}$ & \multirow[t]{2}{*}{$6.9 \times 6.9 \times 6.9 \mathrm{~nm}^{3}$} \\
\hline & & & $333 \mathrm{~K}$ & $200 \mathrm{~ns}$ & \\
\hline \multirow[t]{6}{*}{7} & \multirow[t]{2}{*}{ HEWL } & \multirow[t]{2}{*}{$\mathrm{R} 1$} & $450 \mathrm{~K}$ & $100 \mathrm{~ns}$ & \multirow[t]{2}{*}{$6.9 \times 6.9 \times 6.9 \mathrm{~nm}^{3}$} \\
\hline & & & $333 \mathrm{~K}$ & $200 \mathrm{~ns}$ & \\
\hline & \multirow[t]{2}{*}{ HEWL } & \multirow[t]{2}{*}{ R2 } & $450 \mathrm{~K}$ & $100 \mathrm{~ns}$ & \multirow[t]{2}{*}{$6.9 \times 6.9 \times 6.9 \mathrm{~nm}^{3}$} \\
\hline & & & $333 \mathrm{~K}$ & $200 \mathrm{~ns}$ & \\
\hline & \multirow[t]{2}{*}{ HEWL } & \multirow[t]{2}{*}{ R3 } & $450 \mathrm{~K}$ & $100 \mathrm{~ns}$ & \multirow[t]{2}{*}{$6.9 \times 6.9 \times 6.9 \mathrm{~nm}^{3}$} \\
\hline & & & $333 \mathrm{~K}$ & $200 \mathrm{~ns}$ & \\
\hline
\end{tabular}




\section{Results}

To investigate the conformational change of lysozyme under different $\mathrm{pH}$, root mean square deviation (RMSD) of HEWL was determined from MD trajectories. The time evolution of RMSD of all MD replicas at $\mathrm{pH} 2$ and $\mathrm{pH} 7$ in Figure 1 was used to describe conformational stability at two different temperature levels. The first $100 \mathrm{~ns}$ of each RMSD calculation represented the simulation of lysozyme at $450 \mathrm{~K}$, while the last $200 \mathrm{~ns}$ represented the simulation at $333 \mathrm{~K}$. The data was displayed in different colors - black (R0), red (R1), and green (R2) - that refer three different repeats of the simulations. In $\mathrm{pH} 2$ condition at $450 \mathrm{~K}$ (Figure 1a), the RMSD values of lysozyme in all repeats increased rapidly within the first 30 ns to $1.3 \mathrm{~nm}$, suggesting that the protein started to unfold from the beginning of the simulation and shortly became stable at $30 \mathrm{~ns}$. The time and ensemble average of the equilibrated RMSD at $450 \mathrm{~K}$ and $\mathrm{pH} 2$ was $1.35 \pm 0.15 \mathrm{~nm}$. RMSD values of the simulated HEWL were decreased and became more stable after the systems were cooled down to $333 \mathrm{~K}$, as the averaged RMSD was found at $1.30 \pm 0.10 \mathrm{~nm}$. At this stage, the slight drop of RMSD values denoted the refolding of proteins. For simulations at $\mathrm{pH} 7$ and $450 \mathrm{~K}$ (Figure 1b), the RMSD increased to around $1.30 \pm 0.15 \mathrm{~nm}$ before reaching an equilibrium at around $50 \mathrm{~ns}, 20 \mathrm{~ns}$ slower than those at $\mathrm{pH}$ 2. The RMSD results at a very high temperature of $450 \mathrm{~K}$ implied that the lysozyme structure unfolded faster at the $\mathrm{pH} 2$ condition compared to the lysozyme at the $\mathrm{pH} 7$ condition. No significant drop of RMSD was seen when switching the temperature to $333 \mathrm{~K}$, and hence no protein refolding.

Time evolution of the conformational features of HEWL at $\mathrm{pH} 2$ under a very high temperature $450 \mathrm{~K}$ for $100 \mathrm{~ns}$ was monitored to observe protein unfolding and at the temperature $333 \mathrm{~K}$ for $200 \mathrm{~ns}$ to observe refolding. At pH 2 (Figure 2), most of the alpha- 
helical structures were lost, and the formation of beta-strands was seen towards the ends of all simulation replicas. However, at pH 7 (Figure 3), most of the secondary structures of HEWL were transformed into random coils, and only a few alpha-helical structures were observed.

The transitions from alpha-helixes, which were the major part of native lysozymes, into beta-strands and random coils were quantified through the Ramachandran plot. In the plots, backbone dihedral angles $\phi$ and $\psi$ for each amino acid residue were mapped for the conformational snapshots at the start of the simulations, after $50 \mathrm{~ns}$ of simulations at $450 \mathrm{~K}$, after $100 \mathrm{~ns}$ of simulations at $450 \mathrm{~K}$, and the final snapshots after $300 \mathrm{~ns}$ of simulations at 333 K. In Figure 2 and Figure 3, $\phi$ and $\psi$ angles of Ramachandran plots were displayed within the ranges between $-180^{\circ}$ to $+180^{\circ}$. The regions within $(\phi, \psi)$ space of alpha-helical structures were around $\phi=-57^{\circ}$ and $\psi=-47^{\circ}[38]$, while the regions for beta-strands were around $\phi=-$ $130^{\circ}$ and $\psi=+140^{\circ}$. For the three HEWL simulations at $\mathrm{pH} 2$, the states of some amino acid residues were shifted from the alpha-helix region within the phase space to the beta-strand region, while some other amino acids were found shifted to other regions that corresponded to either the random-coils or the intermediate states between the alpha-helices and the betastrands. The alpha-beta transitions occurred less frequently for the non-protonated proteins at $\mathrm{pH} 7$ (Figure 3), in which a large number of amino acid residues found at the intermediate states signified the incomplete refolding process as observed from the conformational snapshots.

The conformational changes were also monitored by the DSSP (Define Secondary Structure of Protein) algorithms (Figure 4 and 5) [37], displaying the plots of different secondary structure contents as a function of amino acid position (residue) and time. When the atomistic coordinates from x-ray crystallographic data or MD simulations are provided, DSSP can identify the types of secondary structures for all the amino acid residues from patterns of hydrogen bonding network. DSSP provided more quantitative analysis on the alpha-beta transition observed in our simulations at different $\mathrm{pH}$. The analysis on the starting structure 
showed that the alpha-helix content within the native HEWL was $32.5 \%$ of the whole structure at $\mathrm{pH}$ 2, and $34.1 \%$ at $\mathrm{pH} 7$ (Figure 5). Meanwhile, the beta-sheet or beta-strand content within the native HEWL was $6.2 \%$ of the whole structure at both $\mathrm{pH}$ values. During $300-\mathrm{ns}$ simulations at $450 \mathrm{~K}$ and $333 \mathrm{~K}$, the structures of HEWL were unfolded and then refolded, causing the percentage of alpha-helix and beta-sheet contents to change for all replicas. After the simulations finished, the percentage of alpha-helix content was found between $0.0 \%-4.4 \%$ at $\mathrm{pH} 2$ and $0.1 \%-13.0 \%$ at $\mathrm{pH} 7$, suggesting that the full protonation on HEWL at $\mathrm{pH} 2$ (Figure 4) corresponded to more alpha helix loss. However, the percentage of beta-sheet content was found between $9.1 \%-19.1 \%$ at $\mathrm{pH} 2$ and $0.6 \%-3.8 \%$ at $\mathrm{pH} 7$, suggesting that alpha-beta transition was more likely to occur at lower $\mathrm{pH}$.

In summary, our analysis in Figure 2 to Figure 5 was to monitor the conformational changes of HEWL during the MD simulations at $\mathrm{pH} 2$ and $\mathrm{pH} 7$ to observed the effects of protonation at low $\mathrm{pH}$ on the unfolding, refolding and alpha-beta transition for the propensity of amyloidosis. Conformational snapshots were taken, and Ramachandran plots were created at $50 \mathrm{~ns}$ and $100 \mathrm{~ns}$ under an elevated temperature of $450 \mathrm{~K}$ to observe the unfolding stages and at $300 \mathrm{~ns}$ under the lower temperature of $333 \mathrm{~K}$ to observe the refolding into different secondary structures. Beta-strands were more likely to form at $\mathrm{pH} 2$, while at $\mathrm{pH} 7$ the protein tended to either preserve alpha helices or unfold into random coils.

To elucidate the mechanism of beta-strand formation at $\mathrm{pH} 2$, the radius of gyration $(\mathrm{Rg})$ was calculated as a function of time to monitor changes in the distribution of different compositions of HEWL, including hydrophobic, positively-charged, and negatively-charged amino acids affected by the protonations. Calculations of $\mathrm{Rg}$ were performed for the whole enzyme molecule and were performed separately for groups of positively-charged residues, negatively-charged residues, and hydrophobic residues from each simulation repeat at both 450 $\mathrm{K}$ (Figure 6) and $333 \mathrm{~K}$ (Figure 7) under both $\mathrm{pH}$ conditions. For the starting structure of 
HEWL at $450 \mathrm{~K}$ prior to unfolding, $\mathrm{Rg}$ of the positively charged group, the negatively charged group, and the hydrophobic group were different. Rg of the hydrophobic group was the lowest when compared with the other group as the hydrophobic sidechains were hidden within the inner core of the globular HEWL due to the hydrophobic effect, while Rg of the positively charged group was the highest Rg due to a large number of positive charge residues. The presence of positively-charged residues at the outer shell of HEWL, according to the highest $\mathrm{Rg}$, was caused by Coulomb repulsions.

For all simulations at $450 \mathrm{~K}$ where unfolding occurred, the $\mathrm{Rg}$ profiles were highly fluctuated at both $\mathrm{pH} 2$ and $\mathrm{pH} 7$ due to the high level of thermal energy that disrupted the hydrogen bonds and overcame other molecular interactions. The distributions of positivelycharged, negatively-charged, and hydrophobic compositions of HEWL at pH 2 (Figure 6a, 6b and 6c) could be differentiated by Rg values, similar to the native structure. However, at $\mathrm{pH} 7$ (Figure 6d, 6e and 6f), $\mathrm{Rg}$ values of different amino acid groups tended to converge as the simulation progressed. The separation of $\mathrm{Rg}$ profile at $\mathrm{pH} 2$ could be explained as the higher amount of positive charge caused stronger Coulomb repulsion between all positively charged residues. On the other hand, the mixing of $\mathrm{Rg}$ profiles between all amino acid groups at $\mathrm{pH} 7$ suggested that the compositions of HEWL became more uniformly distributed as the protein unfolded. When the temperature of all simulations was reduced to $333 \mathrm{~K}$, the $\mathrm{Rg}$ profiles became less fluctuated, but similar trends were preserved for both $\mathrm{pH} 2$ (Figure 7a, 7b and 7c) and pH 7 (Figure 7d, 7e and 7f).

From Figure 8, clustering of the hydrophobic sidechains was observed underneath the beta-sheets formed at the surface of the refolded proteins at $333 \mathrm{~K}$. The formation of hydrophobic clusters within the core of the protonated HEWL, as the protonation neutralized the negatively charged residues and caused the total charge of the system to be further positive. Coulomb repulsion between positively charged residues was the cause of larger $\mathrm{Rg}$ for the 
positively-charged amino acid group, corresponding to the presence of positively charged sidechains at the surface. As a result, the absence of positively charged residues from the core left an amount of space for hydrophobic sidechains to form hydrophobic clusters and thus lessen the Rg of the hydrophobic amino acid group. Meanwhile, the formation of beta-strands or beta-sheets from backbone parts of hydrophobic amino acids was facilitated by the increased compactness (low Rg) of the hydrophobic clusters.

\section{Discussions}

A series of atomistic molecular dynamics (MD) simulations on HEWL under different $\mathrm{pH}$ conditions and conformational analysis of all simulation replicas were performed to understand the effect of low $\mathrm{pH}$ on the unfolding of HEWL and the propensity of refolding into the beta structure. For each replica, HEWL was explicitly simulated under the temperature $300 \mathrm{~K}$, followed by $450 \mathrm{~K}$ and $333 \mathrm{~K}$, in order to accelerate the unfolding and refolding processes to occur within a feasible timescale for MD simulations. RMSD was calculated for the simulations at both $\mathrm{pH} 2$ and $\mathrm{pH} 7$ to monitor the global conformational change or the unfolding of HEWL. No significant change was observed during the first period of all simulations at 300 $\mathrm{K}$, while lysozymes at a high temperature of $450 \mathrm{~K}$ started to unfold from the beginning of all simulations under both $\mathrm{pH}$ conditions. Lysozymes at $\mathrm{pH} 2$ unfolded faster compared to lysozymes at $\mathrm{pH} 7$ due to the added positive charges from the amino acid protonations at low $\mathrm{pH}$. When the temperature was decreased to $333 \mathrm{~K}$, lysozymes tended to refold into betastrands at $\mathrm{pH} 2$, while misfolded into alpha-helices and random coils at $\mathrm{pH}$ 7. The transformation of alpha-helical structures of native lysozymes into beta-strands was also monitored by the Ramachandran plots. At $\mathrm{pH}$ 2, a large number of amino acid residues were moved from the alpha-helix region to the beta-strand region within the phase space of backbone angles, suggesting a large number of alpha-beta transitions. At $\mathrm{pH} \mathrm{7,} \mathrm{however,} \mathrm{most} \mathrm{of} \mathrm{the}$ 
amino acid residues of lysozyme tended to move to either the random-coil regions or to the intermediate states between the alpha-helix and the beta-strand regions. A similar trend was displayed from the time-dependent changes of the percentage of secondary structure contents quantified by the DSSP (Define Secondary Structure of Protein) algorithm. The analysis showed that the percentage of alpha-helix significantly decreased when lysozymes were unfolded at high temperatures for both $\mathrm{pH}$ conditions. However, at the final stages of the simulations, a higher amount of alpha-helix loss and a higher percentage of beta-strand formation were found at low $\mathrm{pH}$. To elucidate the mechanism of these effects of low $\mathrm{pH}$ condition in terms of atomistic structure, the radius of gyration $(\mathrm{Rg})$ was calculated for each of different compositions of HEWL, including the groups of hydrophobic, positively-charged, and negatively-charged amino acids. For the native HEWL structure, Rg values for the hydrophobic and the hydrophilic charged amino acid groups were different. Larger values of Rg were found for the charged amino acid groups, as the more hydrophilic charged amino acid groups energetically prefer the larger amount of contacts with water molecules and to stay further from the center of the protein. Meanwhile, smaller values of Rg were found for the hydrophobic amino acid groups, as they entropically prefer the lower amount of contacts with water molecules and to cluster closer to the center of the protein. For simulations at $450 \mathrm{~K}$ and $\mathrm{pH} 7$, a substantial amount of kinetic energy was introduced with the elevated temperature. The kinetic energy from the global molecular motion overcame the interactions between the charged amino acids and the solvent molecules and the interactions between the hydrophobic sidechains. The random motion that occurred after the interaction network loss resulted in mixing between the hydrophilic and hydrophobic shells during the protein unfolding at $\mathrm{pH} 7$. Interestingly, at $\mathrm{pH} 2$, compositions of HEWL remained separated as hydrophobic and hydrophilic shells even at high temperatures. The separation was caused by the higher amount of Coulombic repulsion between 16 positively charged residues within the lysozymes. At $\mathrm{pH}$ 
7, the electrostatic repulsion was partly screened by the presence of the negatively charged amino acids, but this screening effect became vanished when the negatively charged amino acids were protonated at $\mathrm{pH} 2$. As a result, positively charged residues formed a hydrophilic shell with larger $\mathrm{Rg}$ than the averaged $\mathrm{Rg}$, and the hydrophobic residues stayed closed to the center of the protein globular structure due to the hydrophobic effect and possessed the lower Rg. The formation of beta-strands at the $\mathrm{pH} 2$ condition can then be explained by the clustering of hydrophobic sidechains within the inner core. The higher amount of Coulombic repulsion at lower $\mathrm{pH}$ had driven most of the positively charged sidechain further from the backbone, leaving the backbone to stay at the middle between hydrophobic and hydrophilic shells. The beta-strands were finally formed by nucleation of the ordered backbone part.

\section{Conclusions}

In this study, the beta-strand formation mechanism at the early stage of amyloid fibrilization has been proposed. Lysozyme is one of the amyloid proteins that can misfold into fibrils and cause some diseases. However, the controlled synthetic amyloid fibrils can become useful biomaterials for bioengineering and biosensing applications. Our molecular dynamics simulations showed that beta-strands were more likely to form when HEWL was unfolded at $\mathrm{pH}$ 2. The mechanism of beta-strand formation was explained in terms of the radial distribution of the charged and the hydrophobic amino acids. Protonation of all glutamic acid and aspartic acid residues facilitates a higher amount of Coulomb repulsions. Positively charged side chains were separated from the cluster of hydrophobic side chains, and the backbone part formed beta-strands. Further validation is needed for the beta-strand formation of other amyloid proteins towards the control of fibril production and the prediction of nucleation sites. 


\section{References}

1. Xing L, Fan W, Chen N, Li M, Zhou X, Liu S. Amyloid formation kinetics of hen egg white lysozyme under heat and acidic conditions revealed by Raman spectroscopy. J Raman Spectrosc. 2019;50: 629-640. doi:10.1002/jrs.5567

2. Mishra R, Sörgjerd K, Nyström S, Nordigården A, Yu Y-C, Hammarström P. Lysozyme Amyloidogenesis Is Accelerated by Specific Nicking and Fragmentation but Decelerated by Intact Protein Binding and Conversion. J Mol Biol. 2007;366: 10291044. doi:10.1016/j.jmb.2006.11.084

3. Yoshimura Y, Lin Y, Yagi H, Lee Y-H, Kitayama H, Sakurai K, et al. Distinguishing crystal-like amyloid fibrils and glass-like amorphous aggregates from their kinetics of formation. Proc Natl Acad Sci. 2012;109: 14446-14451. doi:10.1073/pnas.1208228109

4. Sabate R. When amyloids become prions. Prion. 2014;8: 233-239. doi:10.4161/19336896.2014.968464

5. Chiti F, Dobson CM. Protein Misfolding, Functional Amyloid, and Human Disease. Annu Rev Biochem. 2006;75: 333-366. doi:10.1146/annurev.biochem.75.101304.123901

6. Deidda G, Jonnalagadda SVR, Spies JW, Ranella A, Mossou E, Forsyth VT, et al. SelfAssembled Amyloid Peptides with Arg-Gly-Asp (RGD) Motifs As Scaffolds for Tissue Engineering. ACS Biomater Sci Eng. 2017;3: 1404-1416. doi:10.1021/acsbiomaterials.6b00570

7. Das S, Jacob RS, Patel K, Singh N, Maji SK. Amyloid Fibrils: Versatile Biomaterials for Cell Adhesion and Tissue Engineering Applications. Biomacromolecules. 2018;19: 1826-1839. doi:10.1021/acs.biomac.8b00279

8. Hauser CAE, Maurer-Stroh S, Martins IC. Amyloid-based nanosensors and nanodevices. Chem Soc Rev. 2014;43: 5326. doi:10.1039/C4CS00082J

9. Peralta MDR, Karsai A, Ngo A, Sierra C, Fong KT, Hayre NR, et al. Engineering Amyloid Fibrils from $\beta$-Solenoid Proteins for Biomaterials Applications. ACS Nano. 2015;9: 449-463. doi:10.1021/nn5056089

10. Altunbas A, Pochan DJ. Peptide-Based and Polypeptide-Based Hydrogels for Drug Delivery and Tissue Engineering. In: Deming T, editor. Peptide-Based Materials. Berlin, Heidelberg: Springer Berlin Heidelberg; 2011. pp. 135-167. doi:10.1007/128_2011_206

11. Jacob RS, Ghosh D, Singh PK, Basu SK, Jha NN, Das S, et al. Self healing hydrogels composed of amyloid nano fibrils for cell culture and stem cell differentiation. Biomaterials. 2015;54: 97-105. doi:10.1016/j.biomaterials.2015.03.002

12. Li C, Qin R, Liu R, Miao S, Yang P. Functional amyloid materials at surfaces/interfaces. Biomater Sci. 2018;6: 462-472. doi:10.1039/C7BM01124E 
13. Seker UOS, Chen AY, Citorik RJ, Lu TK. Synthetic Biogenesis of Bacterial Amyloid Nanomaterials with Tunable Inorganic-Organic Interfaces and Electrical Conductivity. ACS Synth Biol. 2017;6: 266-275. doi:10.1021/acssynbio.6b00166

14. Kim J-Y, Sahu S, Yau Y-H, Wang X, Shochat SG, Nielsen PH, et al. Detection of Pathogenic Biofilms with Bacterial Amyloid Targeting Fluorescent Probe, CDy11. J Am Chem Soc. 2016;138: 402-407. doi:10.1021/jacs.5b11357

15. Humenik M, Scheibel T. Nanomaterial Building Blocks Based on Spider SilkOligonucleotide Conjugates. ACS Nano. 2014;8: 1342-1349. doi:10.1021/nn404916f

16. Bleem A, Daggett V. Structural and functional diversity among amyloid proteins: Agents of disease, building blocks of biology, and implications for molecular engineering: Amyloid Proteins: Beyond Disease. Biotechnol Bioeng. 2017;114: 7-20. doi:10.1002/bit.26059

17. Mankar S, Anoop A, Sen S, Maji SK. Nanomaterials: amyloids reflect their brighter side. Nano Rev. 2011;2: 6032. doi:10.3402/nano.v2i0.6032

18. Defelice FG, Ferreira ST. Physiopathological modulators of amyloid aggregation and novel pharmacological approaches in Alzheimer's disease. An Acad Bras Ciênc. 2002;74: 265-284. doi:10.1590/S0001-37652002000200006

19. Chen Z, Li L, Zhao H, Guo L, Mu X. Electrochemical impedance spectroscopy detection of lysozyme based on electrodeposited gold nanoparticles. Talanta. 2011;83: 1501-1506. doi:10.1016/j.talanta.2010.11.042

20. Bogomolova A, Komarova E, Reber K, Gerasimov T, Yavuz O, Bhatt S, et al. Challenges of Electrochemical Impedance Spectroscopy in Protein Biosensing. Anal Chem. 2009;81: 3944-3949. doi:10.1021/ac9002358

21. Randviir EP, Banks CE. Electrochemical impedance spectroscopy: an overview of bioanalytical applications. Anal Methods. 2013;5: 1098. doi:10.1039/c3ay26476a

22. Knowles TPJ, Mezzenga R. Amyloid Fibrils as Building Blocks for Natural and Artificial Functional Materials. Adv Mater. 2016;28: 6546-6561. doi:10.1002/adma.201505961

23. Wang W. Protein aggregation and its inhibition in biopharmaceutics. Int J Pharm. 2005;289: 1-30. doi:10.1016/j.ijpharm.2004.11.014

24. Sutthibutpong T, Rattanarojpong T, Khunrae P. Effects of helix and fingertip mutations on the thermostability of xyn11A investigated by molecular dynamics simulations and enzyme activity assays. J Biomol Struct Dyn. 2018;36: 3978-3992. doi:10.1080/07391102.2017.1404934

25. Moraitakis G, Goodfellow JM. Simulations of Human Lysozyme: Probing the Conformations Triggering Amyloidosis. Biophys J. 2003;84: 2149-2158. doi:10.1016/S0006-3495(03)75021-8 
26. Robustelli P, Piana S, Shaw DE. Developing a molecular dynamics force field for both folded and disordered protein states. Proc Natl Acad Sci. 2018;115: E4758-E4766. doi:10.1073/pnas. 1800690115

27. Guvench O, MacKerell AD. Comparison of Protein Force Fields for Molecular Dynamics Simulations. In: Kukol A, editor. Molecular Modeling of Proteins. Totowa, NJ: Humana Press; 2008. pp. 63-88. doi:10.1007/978-1-59745-177-2_4

28. Jafari M, Mehrnejad F. Molecular Insight into Human Lysozyme and Its Ability to Form Amyloid Fibrils in High Concentrations of Sodium Dodecyl Sulfate: A View from Molecular Dynamics Simulations. Hassan I, editor. PLOS ONE. 2016;11: e0165213. doi:10.1371/journal.pone.0165213

29. Jiang Z, You L, Dou W, Sun T, Xu P. Effects of an Electric Field on the Conformational Transition of the Protein: A Molecular Dynamics Simulation Study. Polymers. 2019;11: 282. doi:10.3390/polym 11020282

30. Walker AR, Baddam N, Cisneros GA. Unfolding Pathways of Hen Egg-White Lysozyme in Ethanol. J Phys Chem B. 2019;123: 3267-3271.

doi:10.1021/acs.jpcb.9b01694

31. Sedov IA, Magsumov TI. Molecular dynamics study of unfolding of lysozyme in water and its mixtures with dimethyl sulfoxide. J Mol Graph Model. 2017;76: 466-474. doi:10.1016/j.jmgm.2017.07.032

32. Patel D, Kuyucak S. Computational study of aggregation mechanism in human lysozyme[D67H]. Zhang Y, editor. PLOS ONE. 2017;12: e0176886. doi:10.1371/journal.pone.0176886

33. Liu H-L, Wu Y-C, Zhao J-H, Fang H-W, Ho Y. Structural Analysis of Human Lysozyme Using Molecular Dynamics Simulations. J Biomol Struct Dyn. 2006;24: 229-238. doi:10.1080/07391102.2006.10507115

34. English NJ, Mooney DA. Denaturation of hen egg white lysozyme in electromagnetic fields: A molecular dynamics study. J Chem Phys. 2007;126: 091105. doi: $10.1063 / 1.2515315$

35. Søndergaard CR, Olsson MHM, Rostkowski M, Jensen JH. Improved Treatment of Ligands and Coupling Effects in Empirical Calculation and Rationalization of $\mathrm{p} K_{\mathrm{a}}$ Values. J Chem Theory Comput. 2011;7: 2284-2295. doi:10.1021/ct200133y

36. Olsson MHM, Søndergaard CR, Rostkowski M, Jensen JH. PROPKA3: Consistent Treatment of Internal and Surface Residues in Empirical p $K_{\mathrm{a}}$ Predictions. J Chem Theory Comput. 2011;7: 525-537. doi:10.1021/ct100578z

37. Kabsch W, Sander C. Dictionary of protein secondary structure: Pattern recognition of hydrogen-bonded and geometrical features. Biopolymers. 1983;22: 2577-2637. doi:10.1002/bip.360221211

38. Hovmöller S, Zhou T, Ohlson T. Conformations of amino acids in proteins. Acta Crystallogr D Biol Crystallogr. 2002;58: 768-776. doi:10.1107/S0907444902003359 
bioRxiv preprint doi: https://doi.org/10.1101/2021.03.25.436950; this version posted March 25, 2021. The copyright holder for this preprint (which was not certified by peer review) is the author/funder, who has granted bioRxiv a license to display the preprint in perpetuity. It is made available under aCC-BY 4.0 International license. 
bioRxiv preprint doi: https://doi.org/10.1101/2021.03.25.436950; this version posted March 25, 2021. The copyright holder for this preprint (which was not certified by peer review) is the author/funder, who has granted bioRxiv a license to display the preprint in perpetuity. It is made available under aCC-BY 4.0 International license. 
pH2

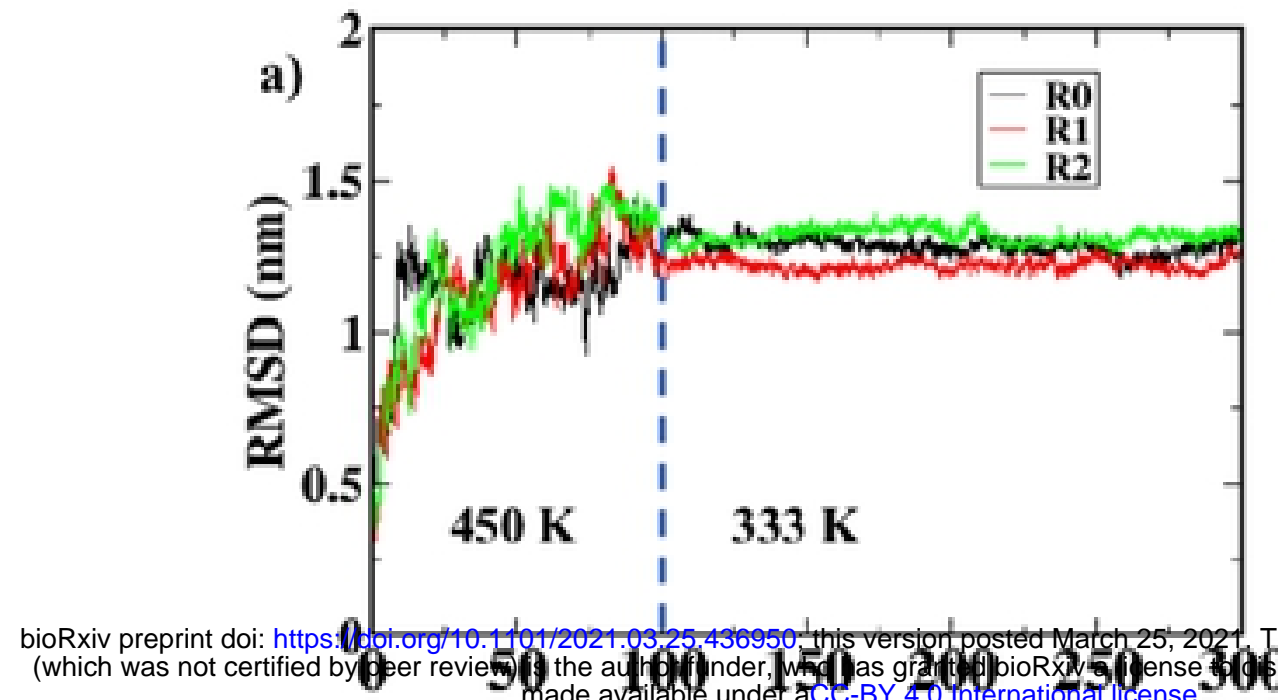

Time (ns)
pH7

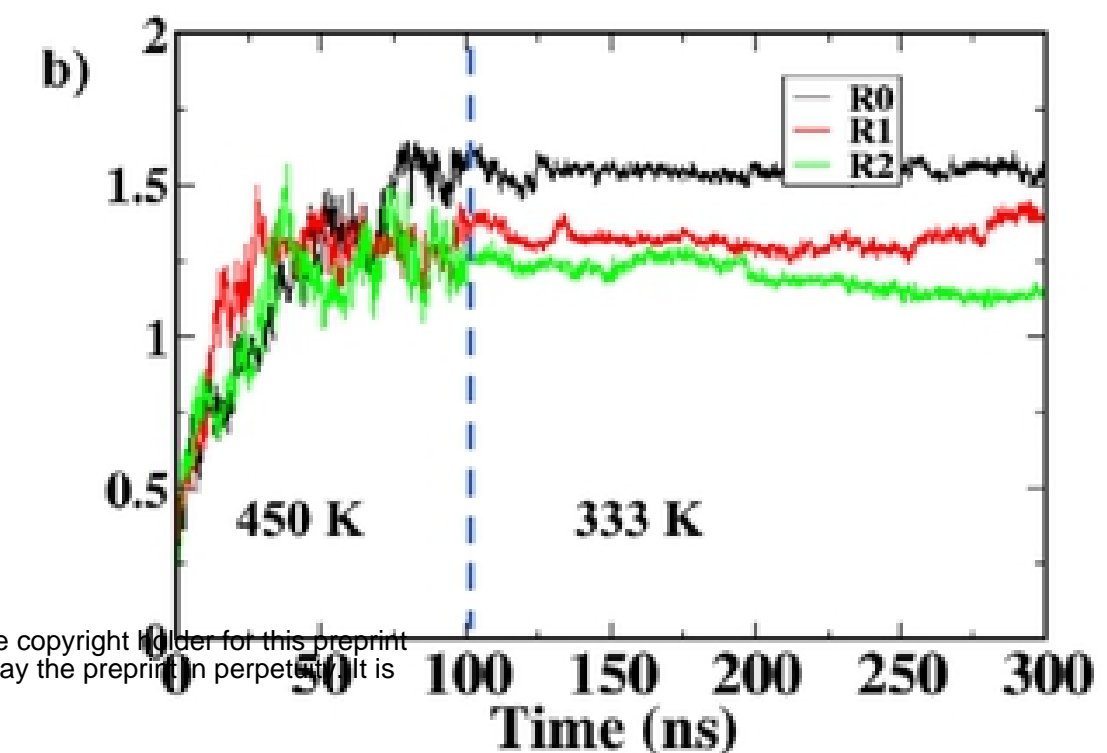

Figure 1: RMSD calculated as functions of time for three replicas of HEWL simulations at (a) $\mathrm{pH} 2$ and (b) $\mathrm{pH}$ 7. Vertical dashed lines represent the time $\mathrm{t}=100 \mathrm{~ns}$ where the temperature was switched from $450 \mathrm{~K}$ to $333 \mathrm{~K}$. 
a)
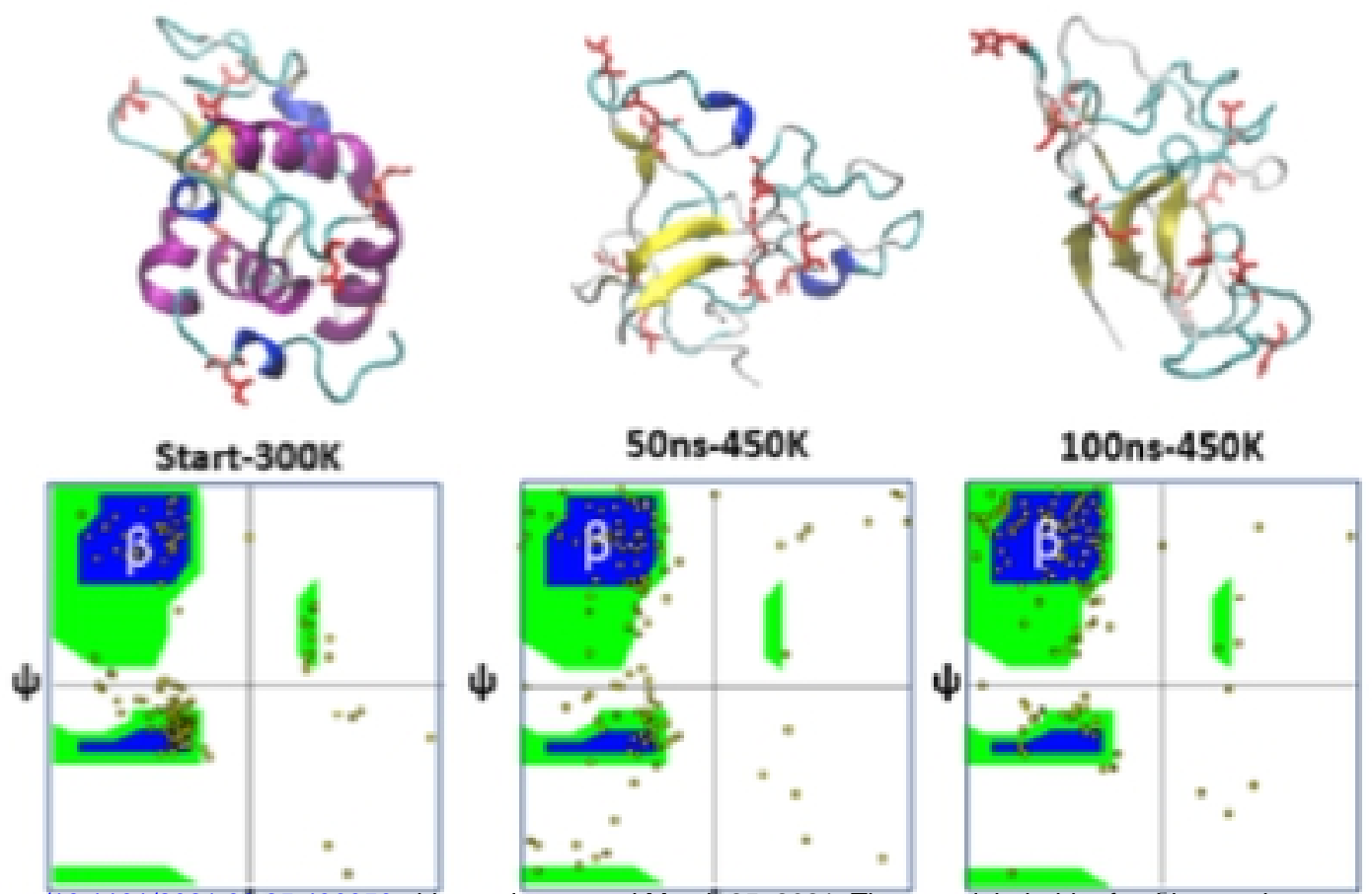

bioRxiv preprint doi: https://doi.org/10.1101/2021.0\% 25.436950; this version posted March 25, 2021. The copyright holder for this preprint
(which was not certified by peer review) is the author/funder, who has granted bioRxiv a license to display the preprint in perpetuity. It is

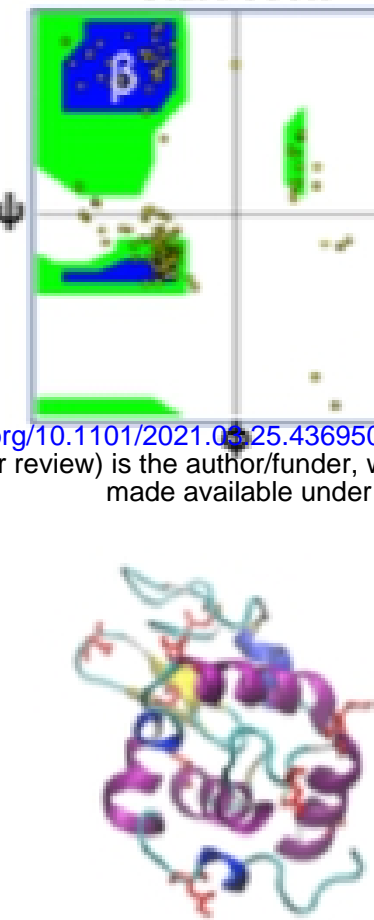

Start-300K
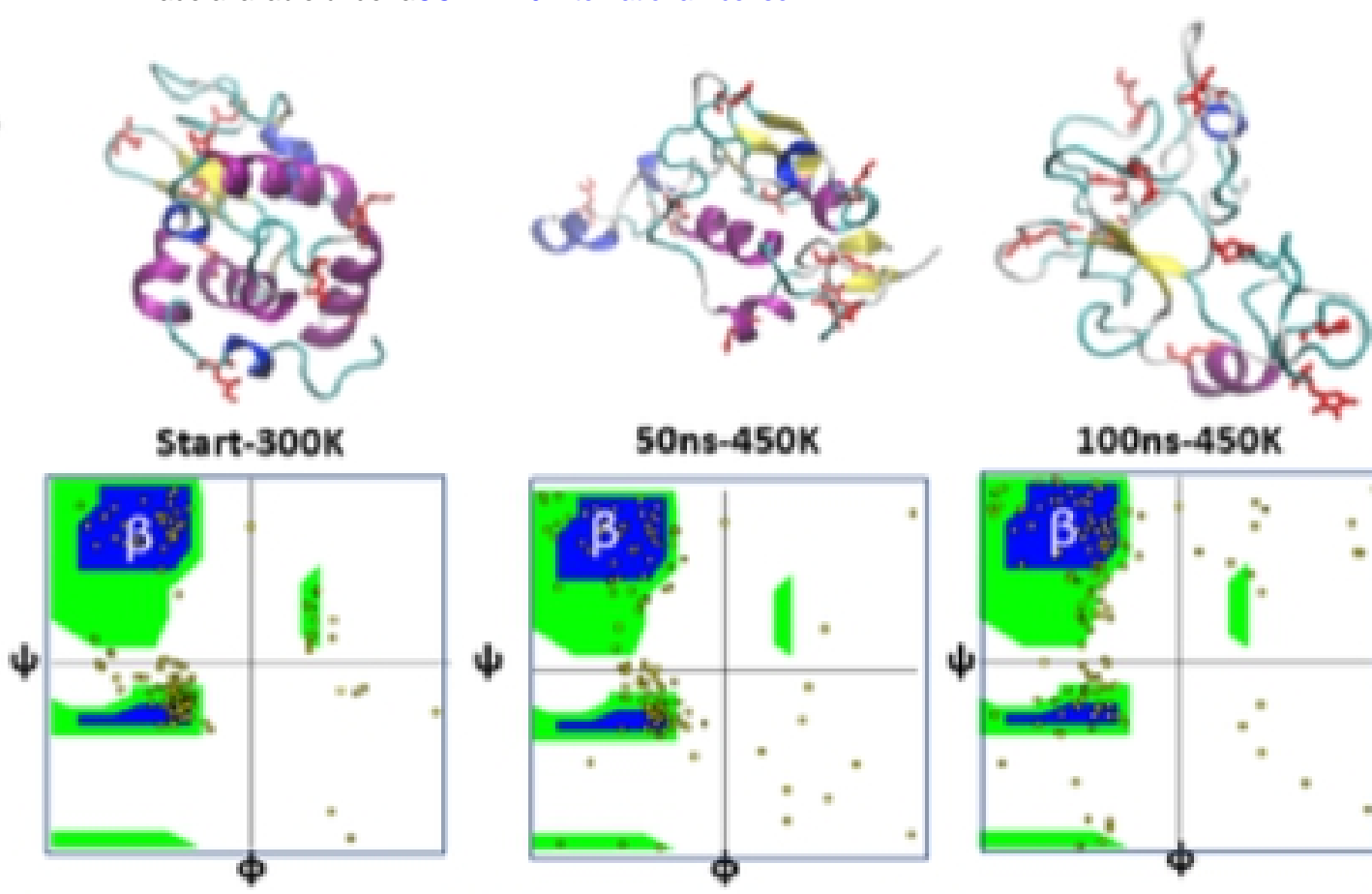

100ns-450K
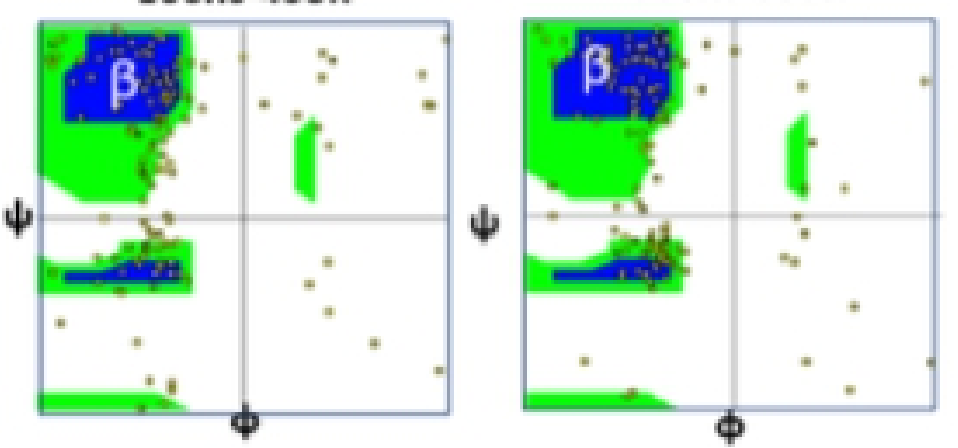

c)
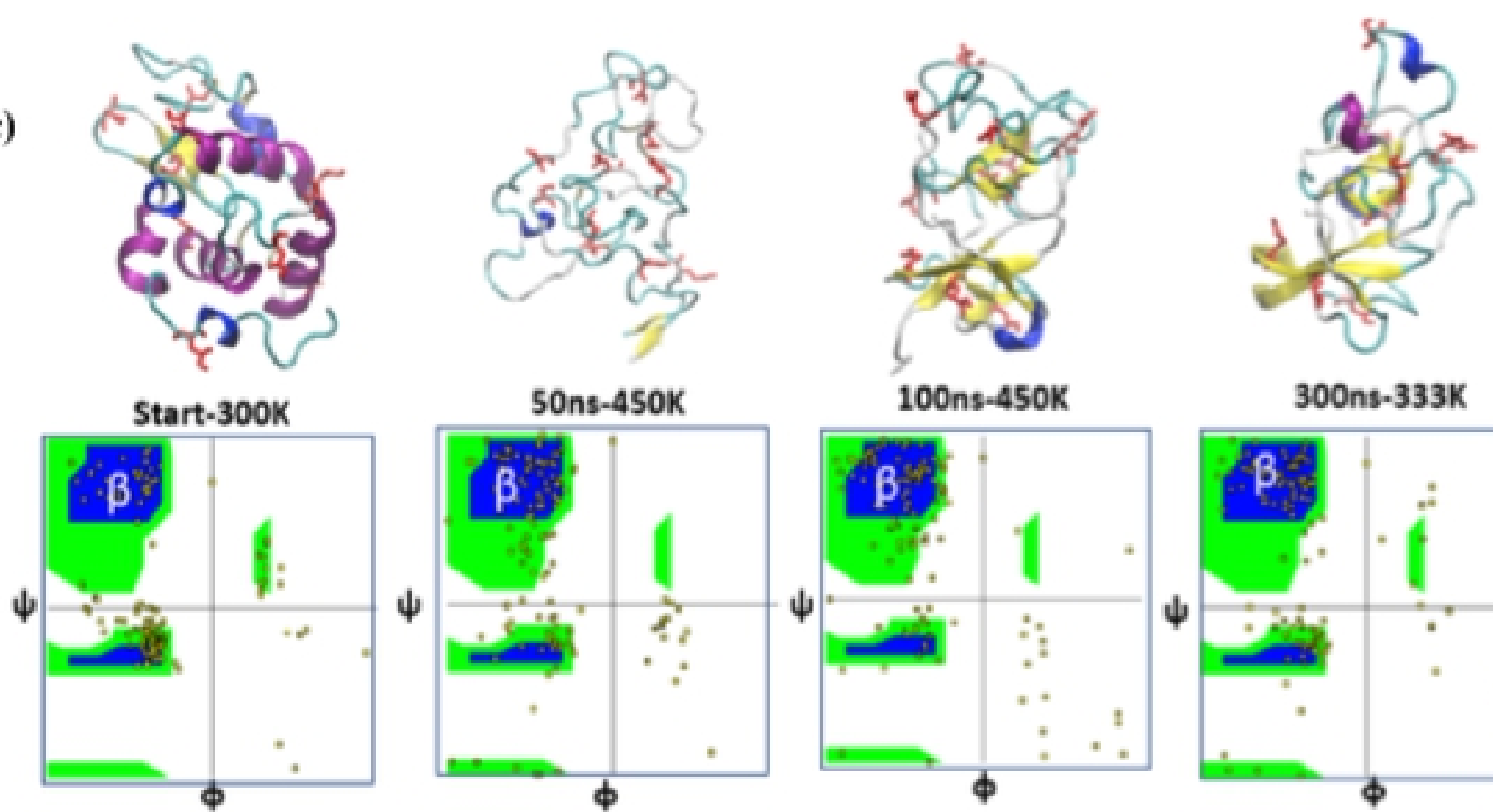

300ns-333K

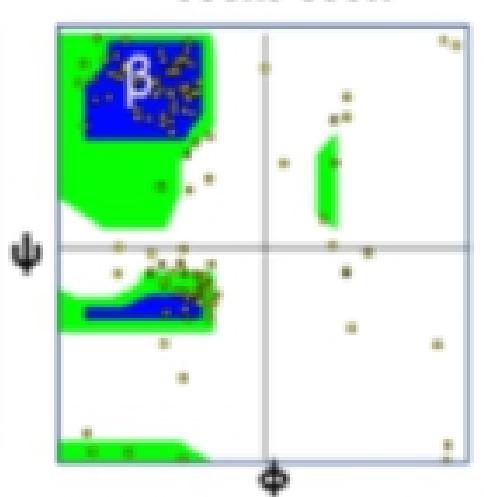

Figure 2: Conformational snapshots of HEWL at $\mathrm{pH} 2$ (top) and ramachandran plots (bottom) for the replicas (a) R0, (b) R1, and (c) R2 taken from at the start, after $50 \mathrm{~ns}$ of simulations at $450 \mathrm{~K}$, after $100 \mathrm{~ns}$ of simulations at $450 \mathrm{~K}$, and after $300 \mathrm{~ns}$ of simulations at $333 \mathrm{~K}$. 
a)
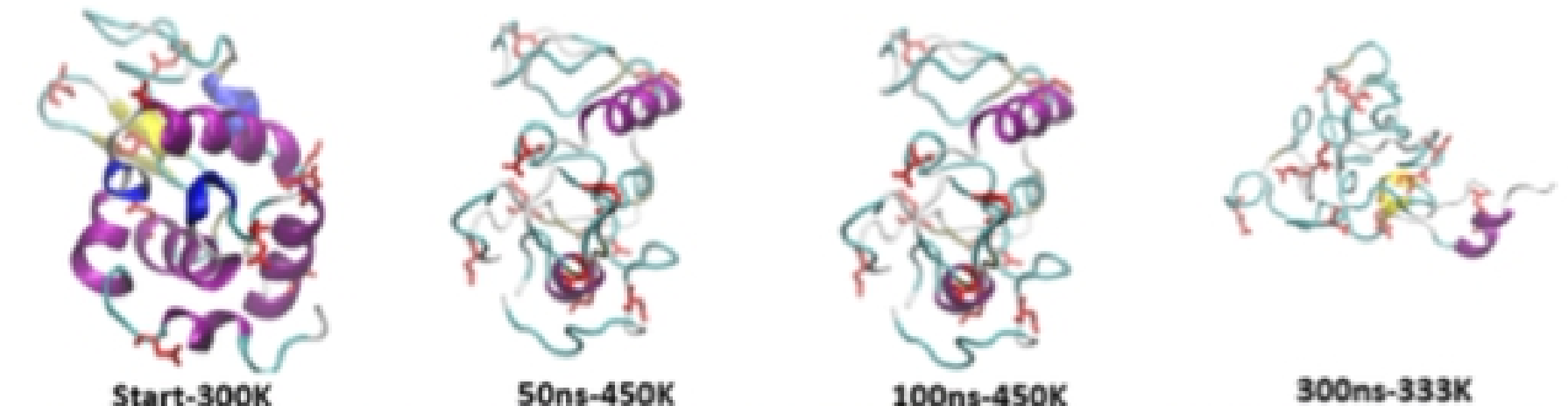

Start-300K
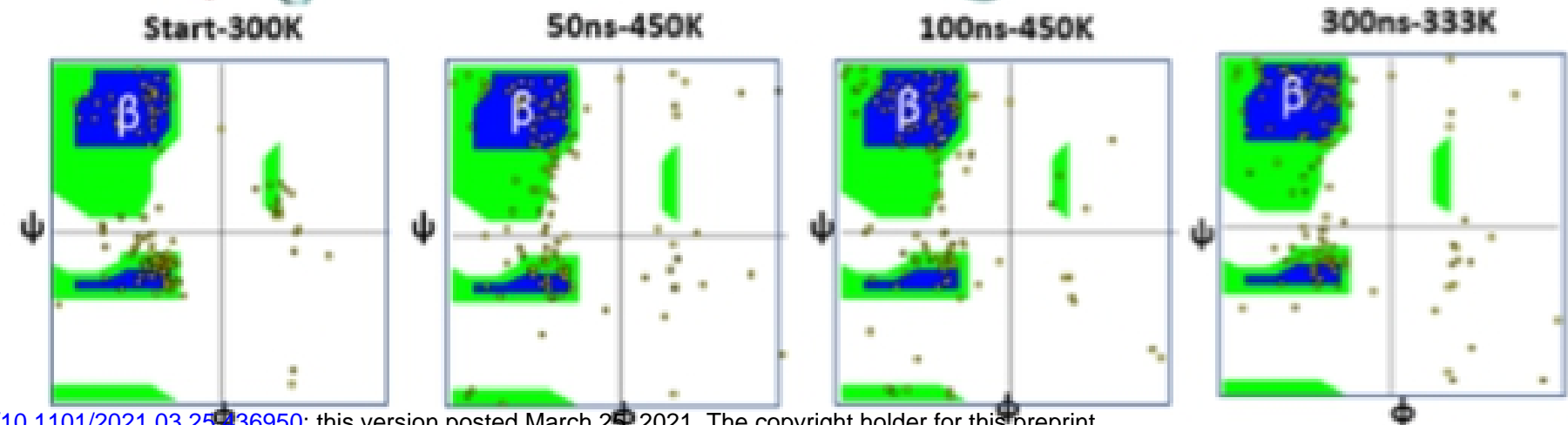

bioRxiv preprint doi: https://doi.org/10.1101/2021.03.25 36950 ; this version posted March 25,2021 . The copyright holder for this preprint
(which was not certified by peer review) is the author/funder, who has granted bioRxiv a license to display the preprint in perpetuity. It is is the author/funder, who has granted bioRxiv a license
made available under aCC-BY 4.0 International license.

b)
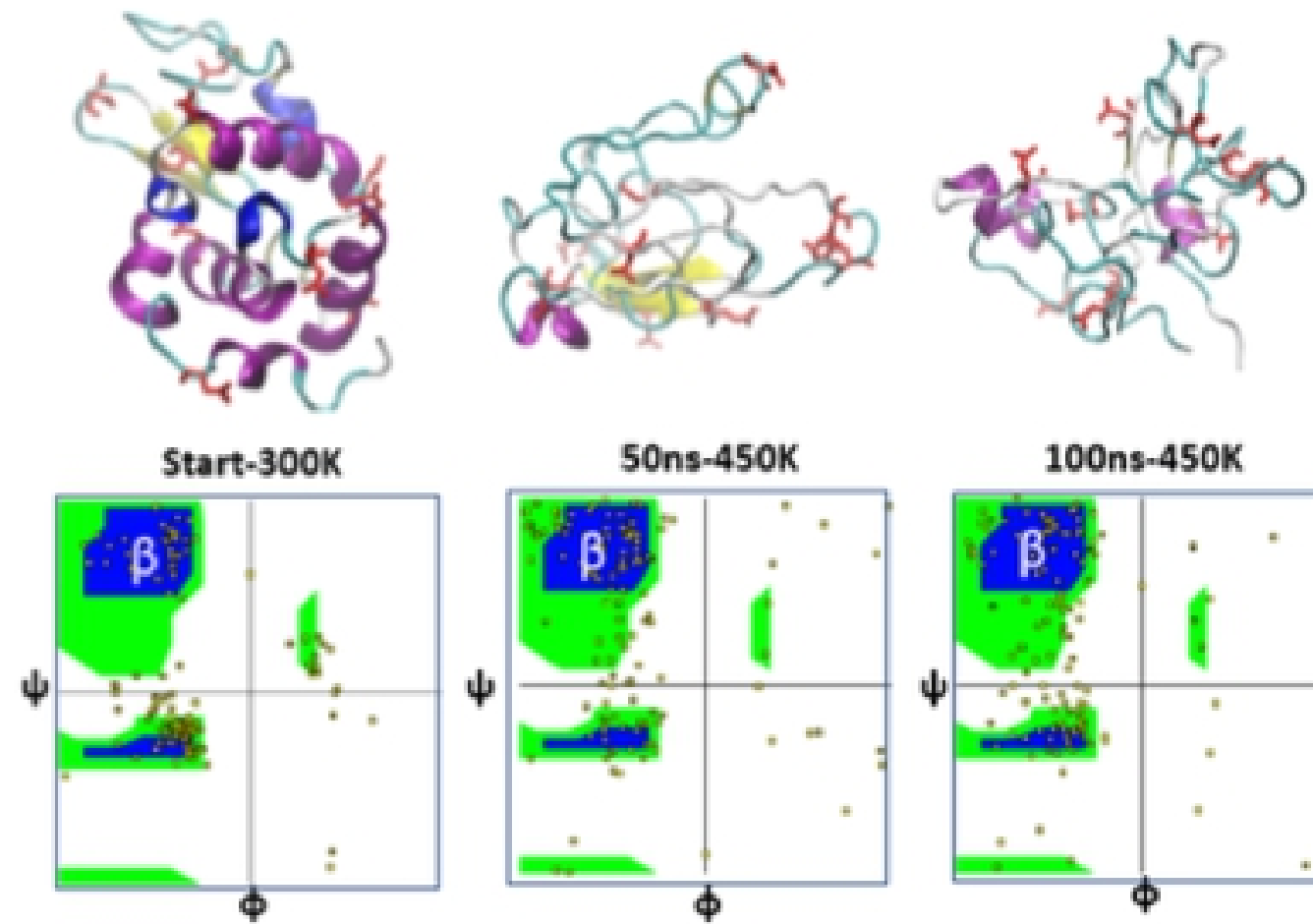

100ns-450K

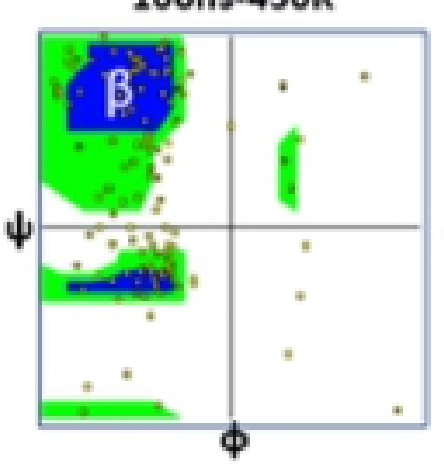

$\Psi$
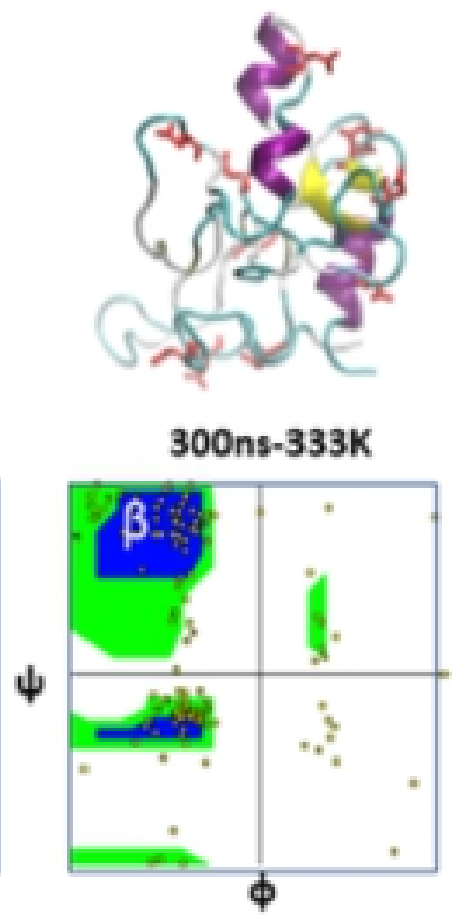

c)

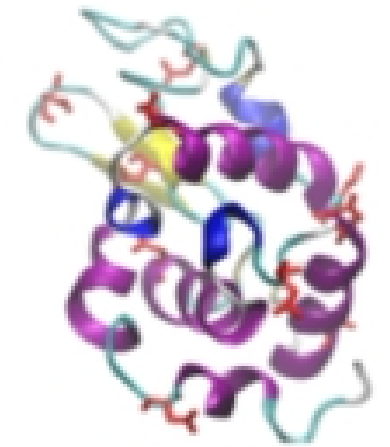

Start-300K

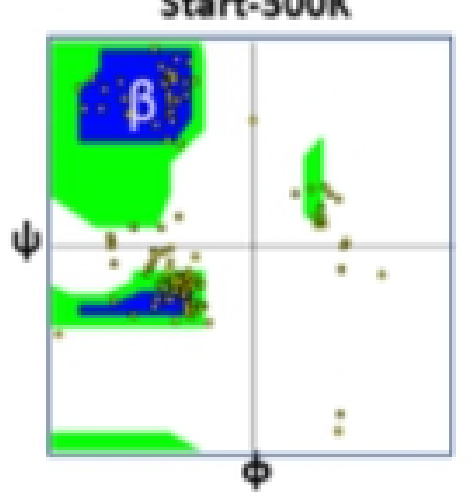

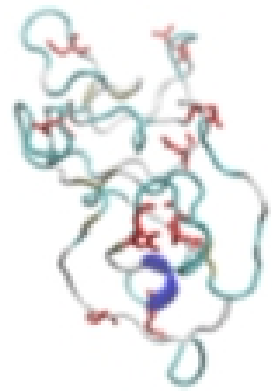

50ns-450K

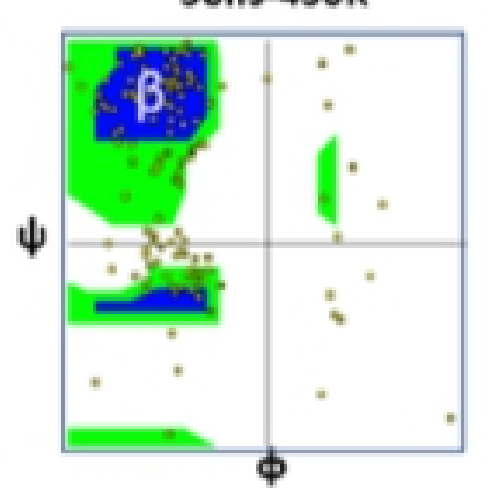

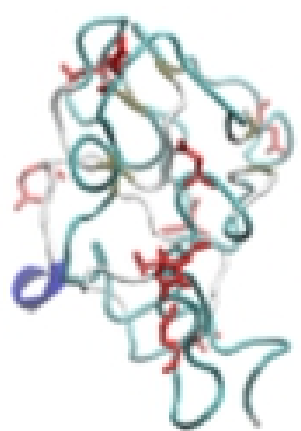

100ns-450K

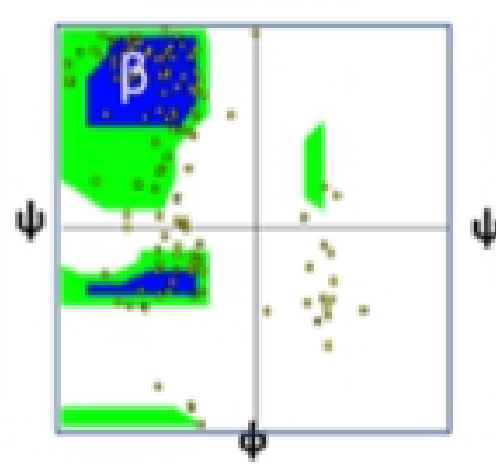

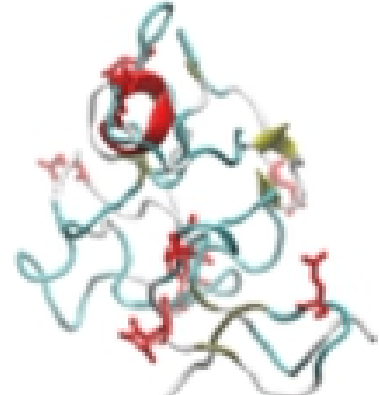

300ns-333K

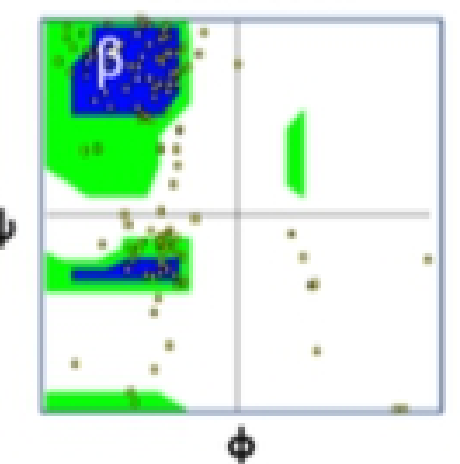

Figure 3: Conformational snapshots of HEWL at pH7 (top) and ramachandran plots (bottom) for the replicas (a) R0, (b) R1, and (c) R2 taken from at the start, after 50 ns of simulations at $450 \mathrm{~K}$, after $100 \mathrm{~ns}$ of simulations at $450 \mathrm{~K}$, and after $300 \mathrm{~ns}$ of simulations at $333 \mathrm{~K}$. 

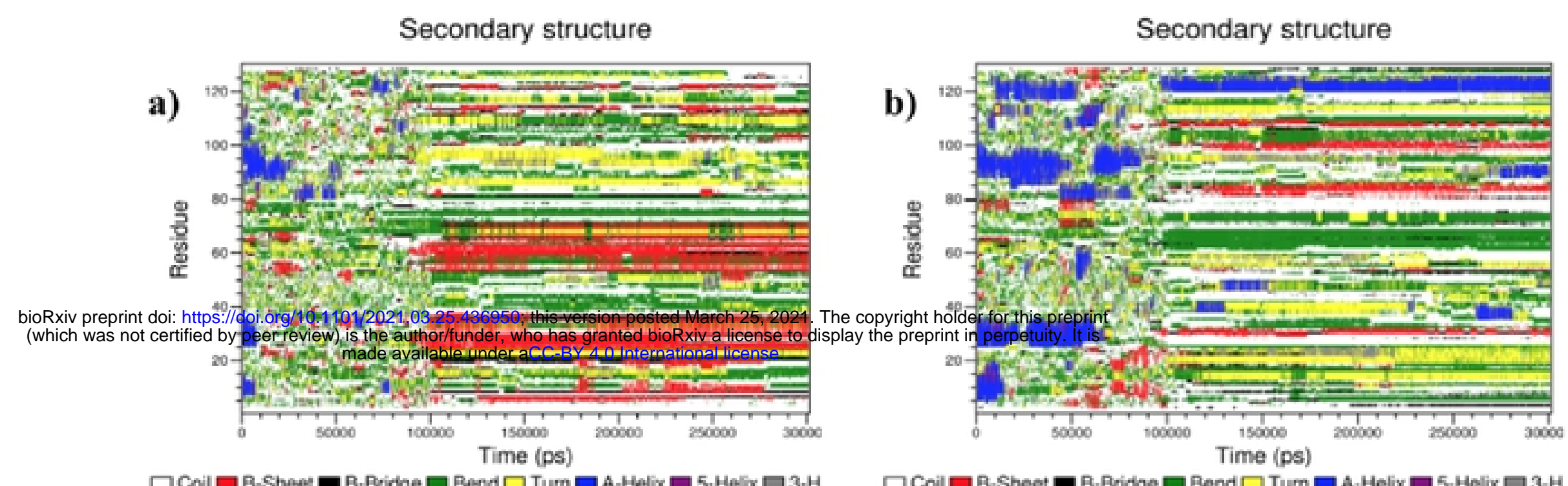

$\square$ Coil $\square$ B-Sheet

B.Bridge $\square$ Bend $\square$ Tum

Secondary structure

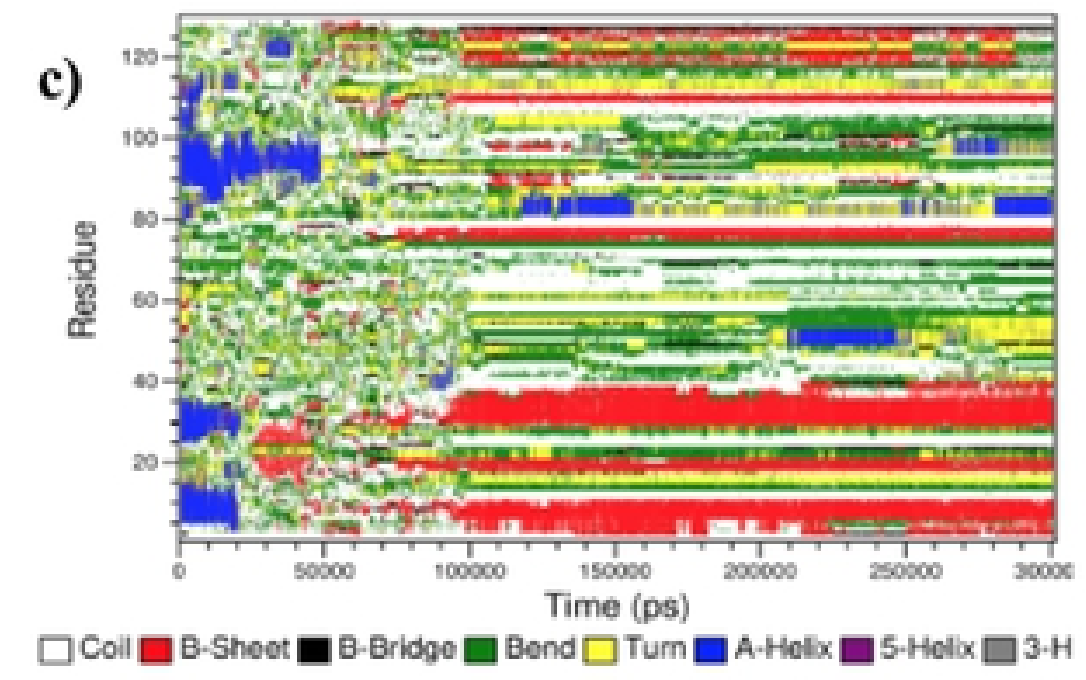

Figure 4: Time evolution of the secondary structures through the DSSP algorithm for the replica (a) $\mathrm{R} 0$, (b) R1, and (c) $\mathrm{R} 2$ at $\mathrm{pH} 2$ 

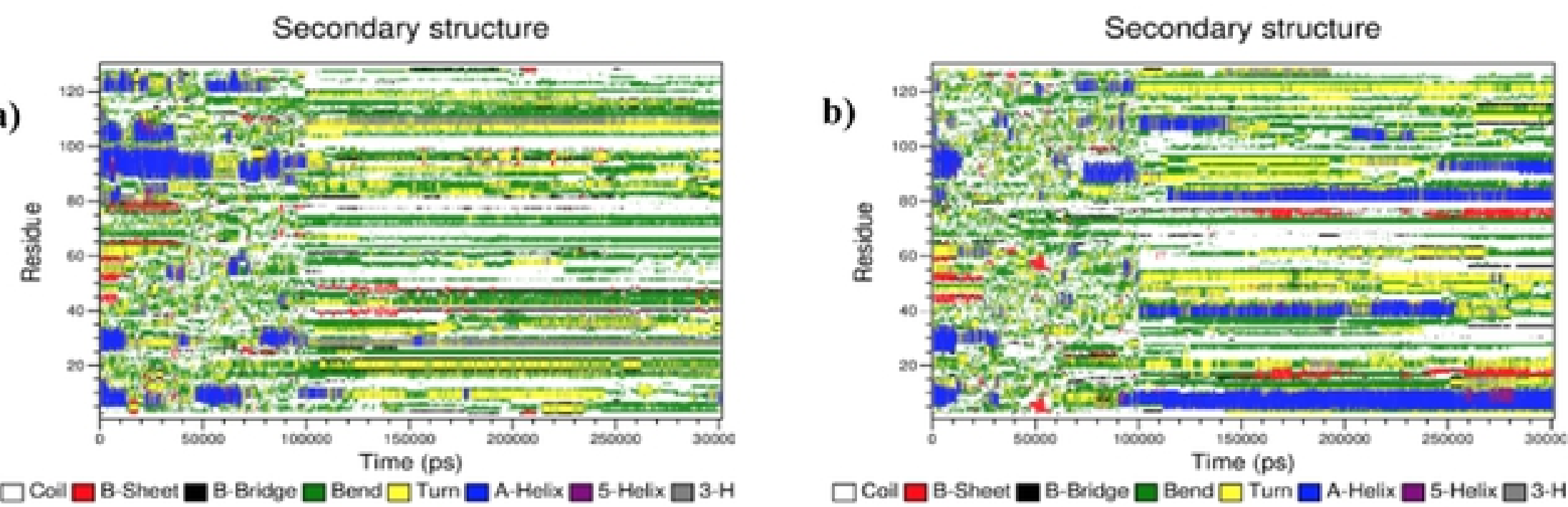

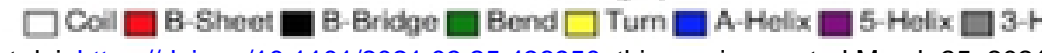

$\square$ Coil $\square$ B-Sheet $\square$ B-Bridge $\square$ Bend $\square$ Tum $\square$ A-Helix $\square$ 5-Helix $\square^{3-H}$

bioRxiv preprint doi: https://doi.org/10.1101/2021.03.25.436950; this version posted March 25, 2021. The copyright holder for this preprint
(which was not certified by peer review) is the author/funder, who has granted bioRxiv a licensetedisplaythy greprietio perpetuity. It is
made available under aCC-BY 4.0 International license.

\section{c)}

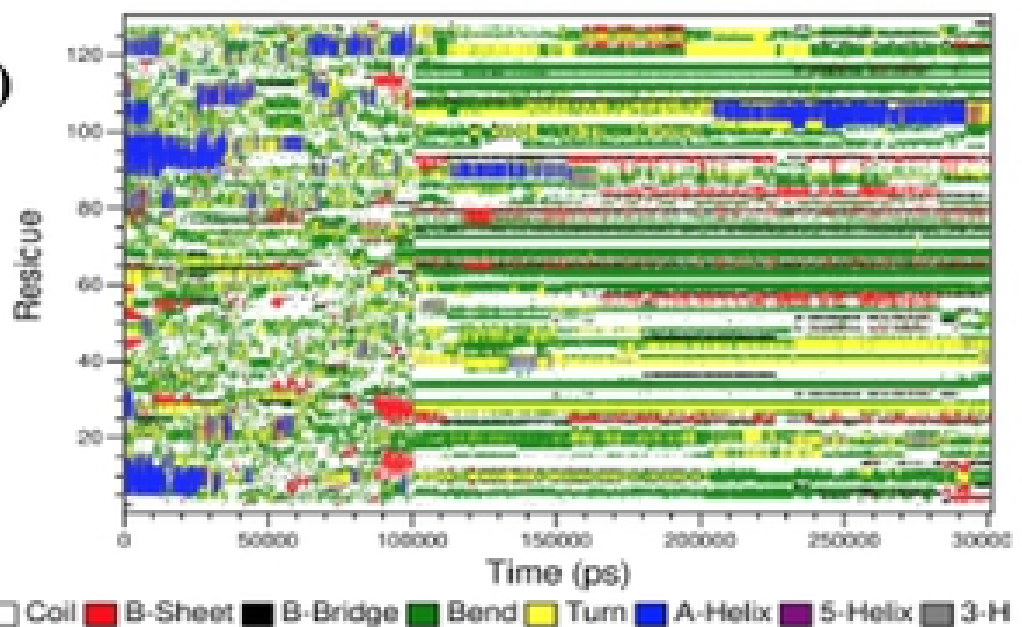

Figure 5: Time evolution of the secondary structures through the DSSP algorithm for the replica (a) $\mathrm{R} 0$, (b) R1, and (c) R2 at $\mathrm{pH} 7$ 


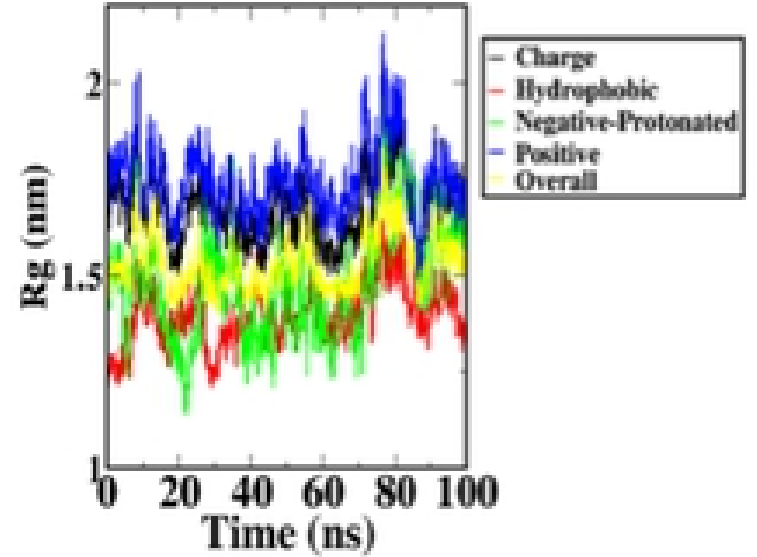

(a) $\mathrm{pH} 2-\mathrm{R} 0$

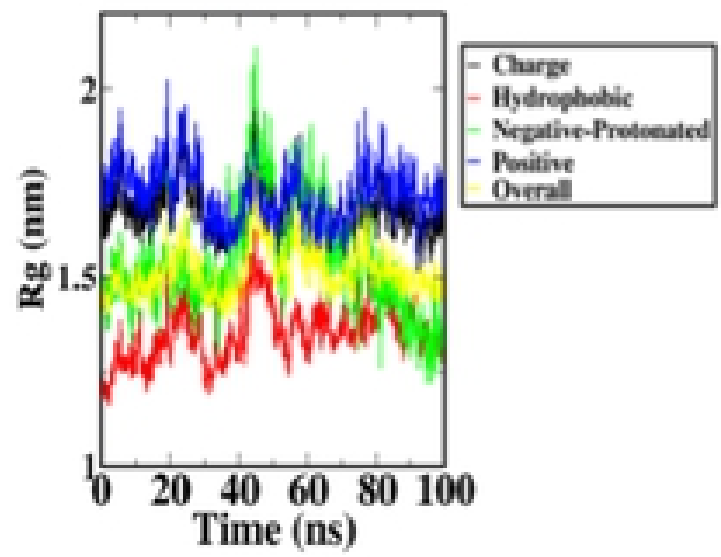

(b) $\mathrm{pH} 2-\mathrm{R} 1$

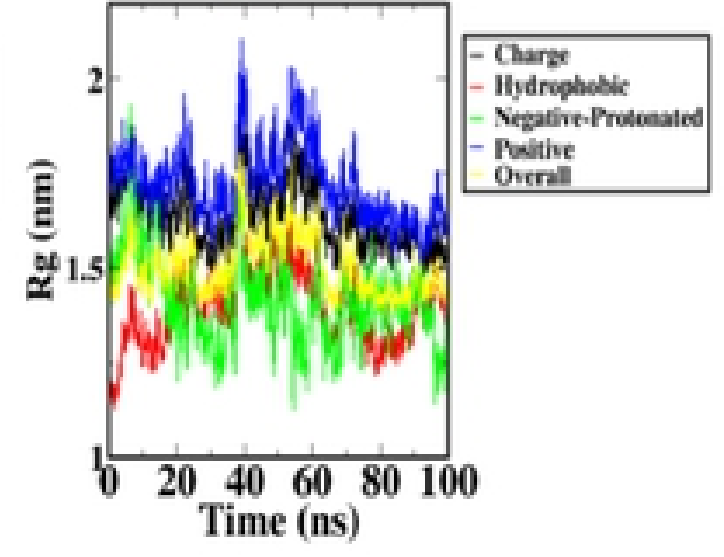

(c) $\mathrm{pH} 2-\mathrm{R} 2$
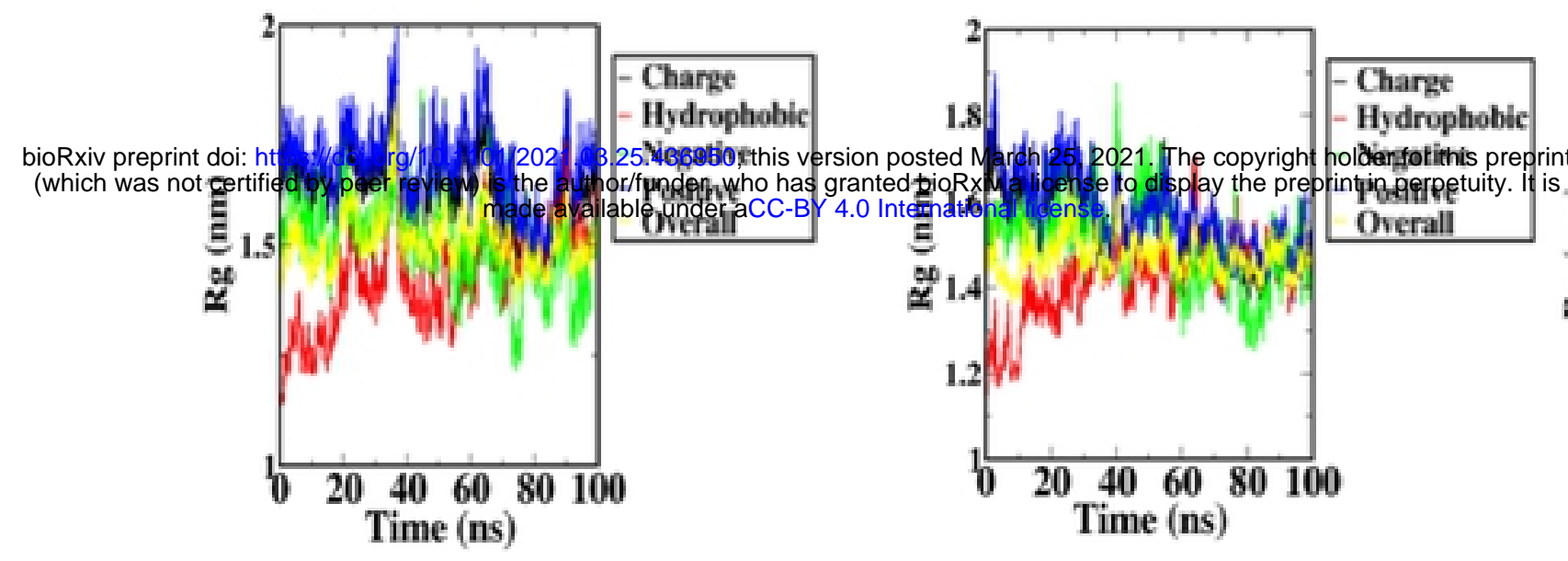

(d) $\mathrm{pH} 7-\mathrm{R} 0$

(e) $\mathrm{pH} 7-\mathrm{R} 1$

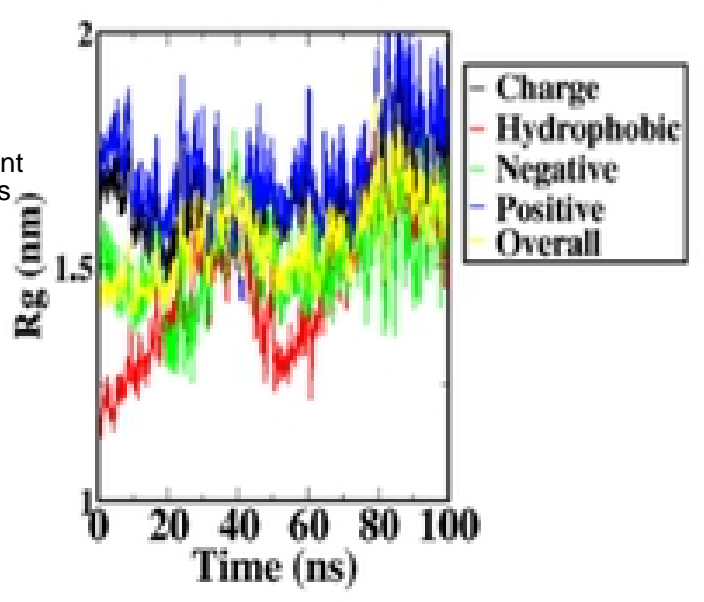

(f) $\mathrm{pH} 7-\mathrm{R} 2$

Figure 6: Radius of gyration calculated as functions of time for all three replaicas of HEWL at $\mathrm{pH} 2$ (a, b and c) and $\mathrm{pH} 7$ (d, e and f) at $450 \mathrm{~K}$. 


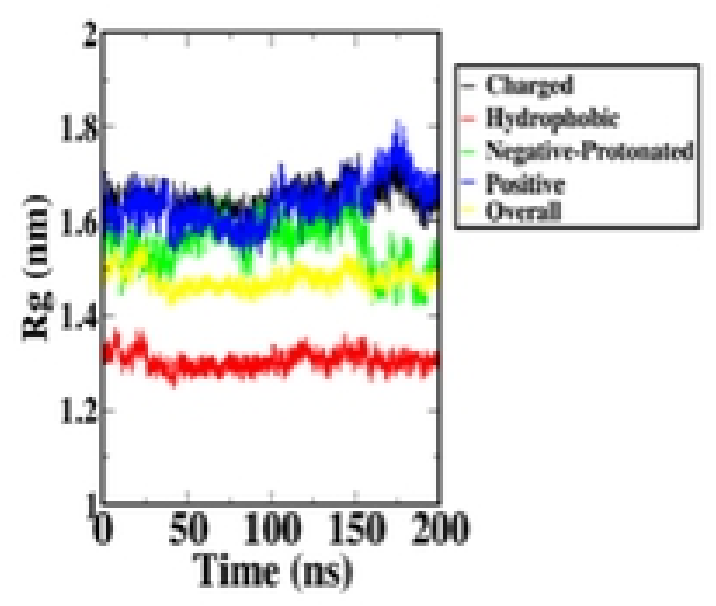

(a) $\mathrm{pH} 2-\mathrm{R0}$

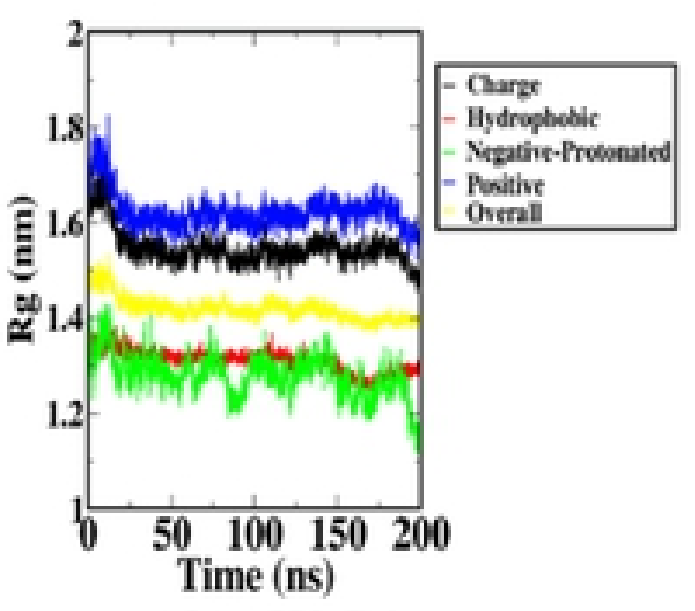

(b) $\mathrm{pH} 2-\mathrm{R} 1$

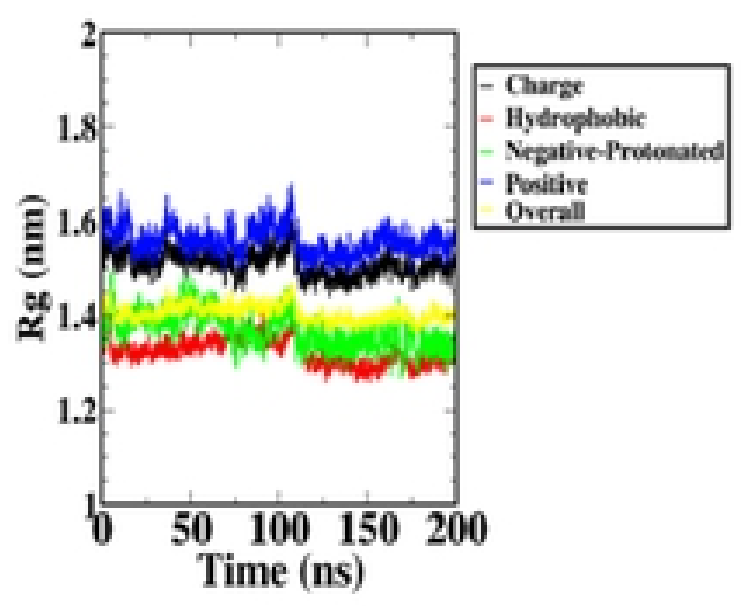

(c) $\mathrm{pH} 2-\mathrm{R} 2$

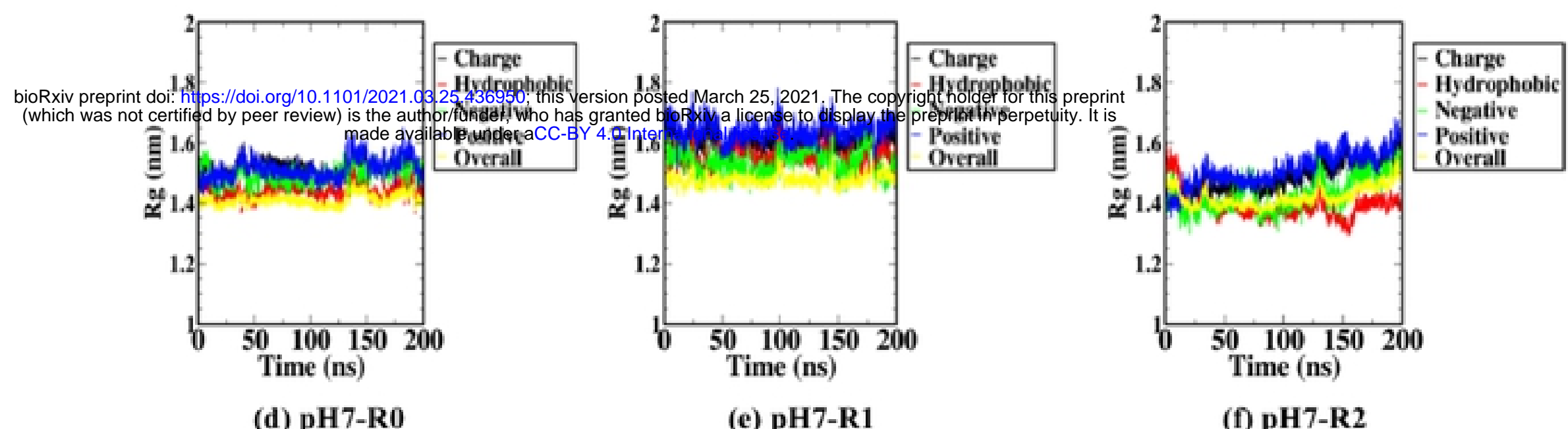

Figure 7: Radius of gyration calculated as functions of time for all three replaicas of HEWL at $\mathrm{pH} 2$ (a, b and c) and $\mathrm{pH} 7$ (d, e and $\mathrm{f}$ ) at $333 \mathrm{~K}$. 
(a)

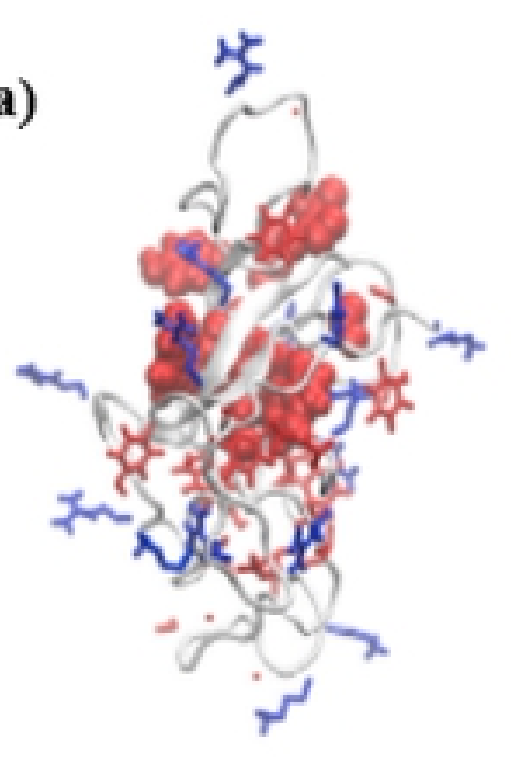

(b)

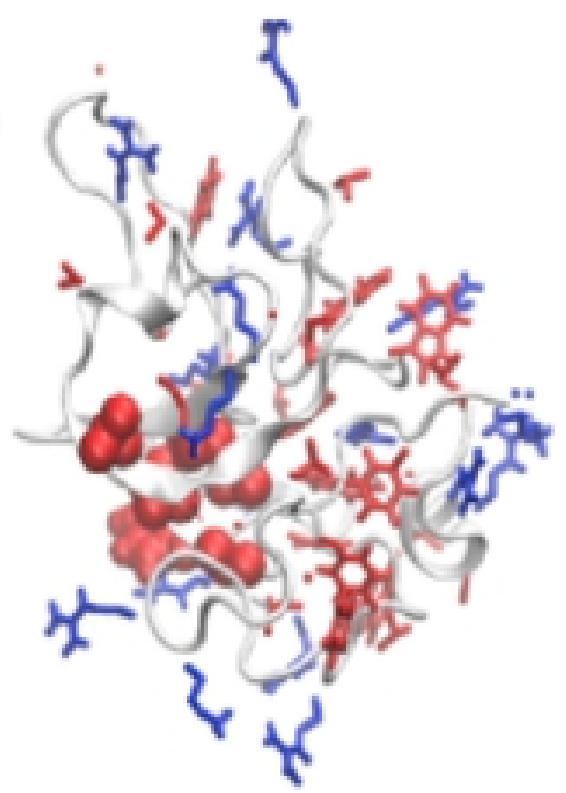

(c)

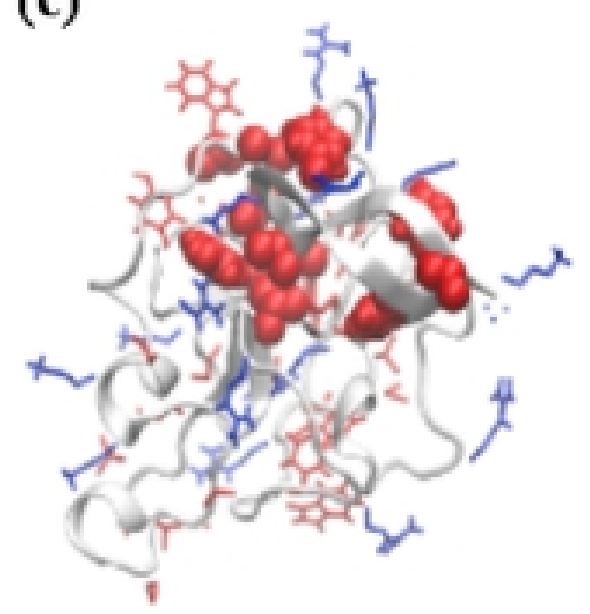
bioRxiv preprint doi: $\mathrm{https} / / / \mathrm{doi}$.org/10.1101/2021.03.25.436950; this version posted March 25,2021 . The copyright holder for this preprint
(which was not certified by peer review) is the author/funder, who has granted bioRxiv a license to display the preprint in perpetuity. It is
made available under aCC-BY 4.0 International license.

Figure 8: Beta strand formation of HEWL for all 3 replicas (a) R0, (b) R1, and (c) R2 under the $\mathrm{pH} 2$ condition at $333 \mathrm{~K}$. Hydrophobic sidechains were represented in red and positively charged sidechains were represented in blue. hydrophobic clusters were shown by the van der Waals atomistic representation. 